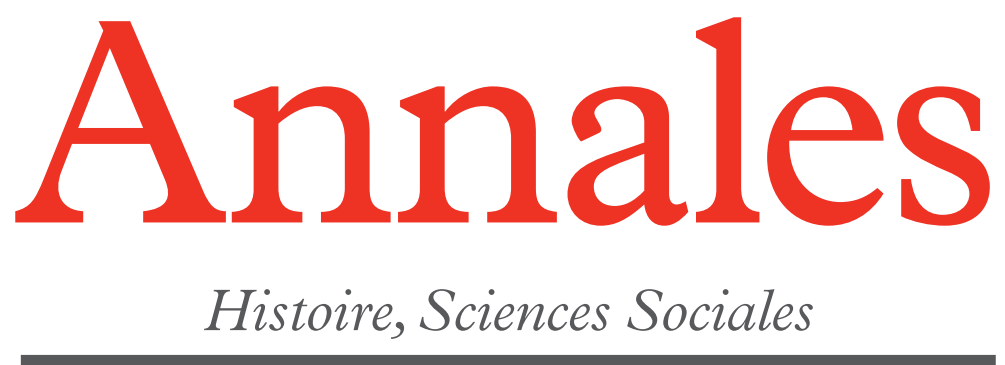

\title{
Revolutionary Violence
}

Francesco Benigno

Francisco Favier Ramón Solans

\section{Sociology and History}

Norbert Elias

Danny Trom

Nicolas Dodier . Fanine Barbot

\section{Writing the History of Science}

Roger Chartier

$71^{\text {st }}$ Year $-\mathrm{n}^{\mathrm{o}} 2$

April-June 2016

ÉDITIONS DE L'ÉCOLE

DES HAUTES ÉTUDES

EN SCIENCES SOCIALES

CAMBRIDGE

UNIVERSITY PRESS 


\section{Annales}

Histoire, Sciences Sociales

$71^{\text {st }}$ Year

no. 2 April-June 2016

\section{Revolutionary Violence}

Francesco BENIGNO

Never the Same Again

On Some Recent Interpretations of the French Revolution

Francisco Javier RAMÓN SOLANS

Being Immortal in Paris

Violence and Prophecy during the French Revolution

\section{Sociology and History}

Danny Trom

Elias on Anti-Semitism: Zionism or Sociology

Followed by a new French translation of Norbert Elias, "Soziologie des deutschen Antisemitismus" (1929)

Nicolas DODIER and Janine BARBOT

The Force of Dispositifs

\section{Writing the History of Science}

Roger CHARTIER

Science and Knowledge

\section{Abstracts}


This English edition of Annales HSS 71, no. 2 (2016) was published April-June 2017.

Editorial information online: http://annales.ehess.fr

Annales Editorial Office

EHESS, 105 boulevard Raspail 75006 Paris (France)

Tel.: +33 (0)153105377

E-mail: annales@ehess.fr

The French edition of the Annales is available in open access on the following platforms:

- Cairn (www.cairn.info/revue-annales.htm), from 2001, with a four-year delay

- Gallica (www.gallica.bnf.fr), from 1929 to 1938

- Persée (www.persee.fr/collection/ahess), 1929-1932, 1939-1941, and 1943-2002

and by subscription through:

- Cambridge Core (www.cambridge.org/annales), from 1929

- Jstor (www.jstor.org/journal/annahistscisoc), from 1929, with a five-year delay

The English edition of the Annales is available on the following platforms:

- Cairn international (www.cairn-int.info/journal-annales.htm), from 2012 to 2016

- Cambridge Core (www.cambridge.org/annales-in-English), from 2012 to current

- Revues.org (www.revues.org), from 2012 to 2016

From 2017, the Annales will be published in print and online by Éditions EHESS in partnership with Cambridge University Press. Subscriptions can be purchased through subscription agents or directly through Cambridge University Press:

Cambridge University Press (Journals)

University Printing House

Shaftesbury Road

Cambridge, CB2 8BS (UK)

journals@cambridge.org

Subscriptions begin with the first issue of the year. Prices and a subscription form can be found at the end of each issue and at www.cambridge.org/annales/subscribe-en.

Sale by issue (French edition only, France, Belgium, and Switzerland): $20 €$

Bookstore orders

CDE (Centre de diffusion de l'édition), 17 rue de Tournon 75006 Paris (France)

Distribution

SODIS, 128 avenue du Maréchal-de-Lattre-de-Tassigny 77400 Lagny-sur-Marne (France)

Sale by issue (international): contact Cambridge University Press

Layout: Michel Rohmer

(C) École des hautes études en sciences sociales, Paris, 2017

ISSN: 2398-5682 (English edition in print), 2268-3763 (English edition online) 


\section{Annales}

Histoire, Sciences Sociales

Founders: Marc Bloch and Lucien Febvre

Former Editor: Fernand Braudel

Quarterly review published since 1929 ,

edited by the École des hautes études

en sciences sociales with

the support of the Centre national

de la recherche scientifique,

the Florence Gould Foundation,

and the American University of Paris

\section{Advisory Board}

Mary Beard, Jane Burbank, Sandro Carocci, Jocelyne Dakhlia, Lorraine Daston, Marc Ferro, François Hartog, António Manuel Hespanha, Christian Lamouroux, Emmanuel Le Roy Ladurie, Alf Lüdtke, André Orléan, Sanjay Subrahmanyam, Pierre-François Souyri, Lucette Valensi

\section{Editor}

Étienne Anheim

\section{Editorial Board}

Vincent Azoulay, Romain Bertrand, André Burguière, Guillaume Calafat, Vanessa Caru, Jean-Yves Grenier, Camille Lefebvre, Antoine Lilti, Jacques Revel, Antonella Romano, Anne Simonin, Laurent Thévenot, Michael Werner

\section{Associate Editors for the English Edition}

Nicolas Barreyre, Stephen W. Sawyer

\section{Assistant Editors}

Aurianne Cox, Séverine Guiton, Chloe Morgan 